Article

2 GAP ASSESMENT OF SOLID WASTE MANAGEMENT 3 (SWM) PRACTICES AND CHALLENGES IN NINE 4 DENSELY POPULATED CITIES OF NEPAL BEFORE 5 AND DURING LOCKDOWN DUE TO COVID-19

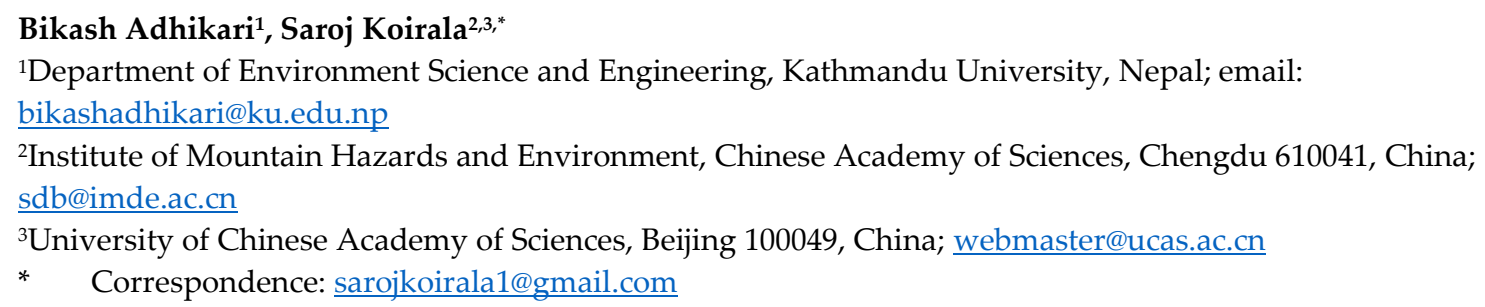

\title{
ABSTRACT
}

The nationwide lockdown imposed to control the spread of novel coronavirus induced dramatic alterations in different sectors of the Nepalese governance including Solid Waste Management (SWM) practices. This study identifies SW collection gaps in nine major cities of Nepal, and highlights the municipal and public hearings on SW management practices before and during the lockdown with a view to emphasize the linkage between Covid-19 and SWM. It includes information on solid waste workers safety practices, collection coverage dynamics, types of vehicles operated for collection and alternative methods adopted by households to manage SW during the collection gaps. It was found that although the coverage of the collection service was similar during the pandemic, there was drastic decrease in the collection frequency leading to a collection gap of 560.58 tons/day and no proper measures were adopted in more than $50 \%$ of the households surveyed for SWM during the collection gap. The study reveals poor occupational health and safety practices among the solid waste workers due to unavailability of safety gears and equipment, in spite of being aware of the modes of transmission of the virus. The pandemic exacerbated the challenges of smooth SWM making its significance as an essential service more apparent. This highlights the need of a timely strategic emergency management framework to be developed by the government to continue the invaluable public service without any hindrance.

Keywords: COVID-19, waste generation, waste collection, gap assessment, emergency plans 


\section{2 of 18}

\section{1. INTRODUCTION}

3 Solid waste management (SWM) has become one of the primary issues, especially in developing countries due to the 4 rapid and unmanaged urbanization. The waste problem, due to the growing global population, consumerism and the 5 linear approach to industrialization, has become an increasingly severe issue in the 21st century [1, 2, 3, 4]. Human 6 activities create waste and these wastes are handled, stored, collected and disposed of, which can pose risks to the 7 environment and to public health [5, 6]. In urban areas, especially in the rapidly urbanizing cities of the developing 8 world, problems and issues of municipal solid waste management (MSWM) are of immediate importance and most 9 governments have acknowledged the importance of MSWM; however, rapid population growth overwhelms the 10 capacity of most municipal authorities to provide even the most basic services [6]. Municipal solid waste is generally a 11 combination of household and commercial refuse which is generated from the living community [7]. According to a 12 study [8] it was estimated that by 20254.3 billion urban residents will be generating $1.42 \mathrm{~kg} / \mathrm{capita} /$ day of municipal 13 solid waste (2.2 billion per year) and from that report it is projected that by 2025 South Asia Region(SAR) will have 14 urban waste generation of $0.77 \mathrm{~kg} / \mathrm{capita} /$ day and 567,545 tons/day with the projected urban population of 734 million.

15 This study has shown that the waste generation in developed countries is more than that in developing country because of the standard of living.

17 Nepal, a developing sovereign country of South Asia Region lies in between $80^{\circ} 41^{\prime}$ and $88^{\circ} 12^{\prime}$ east longitude and $26^{\circ} 22^{\prime}$ 18 and $30^{\circ} 27^{\prime}$ north latitude. Increasing population levels, booming economy, rapid urbanization and the rise in 19 community living standards have greatly accelerated the municipal solid waste generation rate in developing countries $20[9,10]$. Similarly, in case of Nepal increasing population and rapid urbanization are the main cause for municipal solid 21 waste generation. According to new constitution of Nepal 2015, administrative Nepal is divided into 7 Provinces, 77 22 Districts and Municipalities and again these municipalities are classified into urban municipality and rural municipalities. Urban municipality is classified into three categories with their respective counts: 6 Metropolitan cities, 11 Sub metropolitan cities and 753 municipalities.

Coronavirus Disease 2019 (COVID-19) is a respiratory disease caused by the virus named SARS-CoV-2, that was first detected in China [11]. Problems in solid waste management was created amid the lockdown of COVID-19 in major populated cities and municipalities of Nepal due to the decrement in collection frequency of MSW. It was found that there was certain gap in collection frequency. Improper management of MSW through open burning, open dumping and unsanitary landfilling contributes to many environmental problems, such as global warming, ozone depletion, human health hazards, ecosystem damages, abiotic resource depletion, etc. [12] . As no other researches are done for the SWM during the pandemic crisis in Nepal so, to know the status of unmanaged MSW, public reaction on unmanaged MSW and collection frequency, before and during lockdown of COVID-19 is the aim of this research.

\section{METHODOLOGY}


3 of 18

\subsection{Municipal and Public Data}

A survey questionnaire including SW collection frequency before and during lockdown, SW management techniques and SW collection medium was circulated in two phases at the target areas. Among 1451 public respondents of the area surveyed, an average of five respondents were ensured from each ward. Municipal data was collected through questionnaires with the municipal officers, environment officers and private organizations. The public respondent data was monitored to be in compliance with the municipal data.

\subsection{Data analysis}

The data obtained was analyzed in Statistical Package for the Social Sciences (SPSS) software developed by IBM. The software is used to perform statistical analysis in research. A codebook is prepared in SPSS where selected cities, types of vehicles used for SW collection, frequency of collection and its management type are assigned a particular code. These codes are numeric and represent the respective variable they are assigned to.

\section{RESULTS AND DISCUSSION}

\subsection{Status of SW Collection}

\section{A. Selected cities data before and during lockdown}

Figure 1(a) shows the status of Solid Waste Collection before and during lockdown. Figure 1(b) shows the overall Solid Waste collection gaps in the selected areas of study. The results show that Kathmandu valley including of Kathmandu metropolitan city, Lalitpur Sub-Metropolitan City and Bhaktapur municipality experiences SW collection gap of around 880 tons per day. This shows a great mismanagement of SW collection in the valley. There are around 25 companies assigned in the valley for waste management which currently charges each household Rs 250 to Rs 300 . The Kathmandu Metropolitan City reports many of the companies not being in communications with the municipal government due to the strong hesitation by the company's solid waste workers to collect solid waste as they are at heightened risk of contracting Covid-19 not from person-to-person but from objects that have been discarded by the infected personnel. The Solid Waste Management Association of Nepal (SWMAN) claims that the coverage of SW collection have been same in all areas of its service operation but the figures for the collection frequency might have changed due to the changes in mobilization of solid waste workers and less MSW generation as there has been scare or no commercial waste production due to the nation-wide lockdown. Also the collection services was interrupted causing the pre-collected waste to be on-hold at Teku Dumping Site as the disposal of waste at the Sisdol Landfill site was halted for a week due to the protest by locals claiming the spread of the coronavirus in their locality through the wastes collected from different communities of the Kathmandu Valley. One of the private companies in Kathmandu reports inadequate supplies of personal protective equipment and other safety gears being one of the reasons behind hesitation of solid waste workers to resume their works as they had been supplied only with gloves and masks for waste collection and handling. The attitude of local people towards solid waste workers further adds up to their challenge as they had been accused as modes of retransmission of virus to community people at some of the places. 


$$
4 \text { of } 18
$$

69 The results show that Butwal Sub-Metropolitan city experiencing a collection gap of about 5 tons/day. The 70 environmental officer of Butwal Sub-Metropolitan city reports that the SW collection services have been unaltered 71 during the lockdown and the figures showing the collection gap is due to reduced SW generation as the schools, 72 colleges and commercial centers have been completely shut down. The Sub-Metro adds that the health and safety of 73 solid waste workers in their area has been its matter of primary concern and thus it has been providing the workers with safety gears and equipment in order to ensure continual services.

Itahari Sub-Metropolitan experienced a collection gap of 23.58 tons/day. The collection frequency declined abruptly due to the fear of virus to the workers and local people. The environmental officer reported the increase in solid waste from household and slaughterhouses and decrease in waste generation from schools and industries. In the first 14 days of lockdown, waste management facility was completely halted. The local management seems optimistic in trying to fill the collection gap and to treat the waste generated effectively. Metro has also experienced increase in incineration and waste being dumped in nearby riverside areas which has recognized be possible sites for various air-borne diseases during this lockdown. The waste management facility covers 22 wards of the sub-metropolitan.

In Pokhara Metropolitan City, solid waste collection in ward 6, 11, 12, 13, 14 is monitored by a non-governmental company and according to the chief executive of that company that the collection frequency has reduced to once a week and the waste collection rate is around 20-25 tons /day. They claim that the reduction in frequency is due to low budget during lockdown of COVID-19. While waste collection in ward no. 1, 2,3 5, 7,8, 9, 10, 14, 15, 17, is observed by another private agency and rest wards are monitored by Pokhara Metropolitan City office. In overall the collection rate has dropped from governmental and private organization officials' statements and it is shown in fig 1(a). From the official's point of view waste generation from tourist area, educational sites have reduced while increased in case of households.

According to governmental official of Hetauda Sub metropolitan city that waste collection in all wards is looked upon by sub-metropolitan city itself. In wards 1, 2, 4, 5, 10 collection frequency is as usual before and after lockdown and in rest of the wards collection frequency has reduced. Tentatively the waste collection in Hetauda sub metropolitan city has reduced according to officials and public as seen in fig.1(a).

94 From governmental official of Nepalgunj sub metropolitan city waste collection rate has decreased creating a waste 95 collection gap of around 9 tons waste per day. According to the statement of official, fear of virus among the staffs and 96 officials is the main reason behind the lag in waste collection. But they are still maintaining collection frequency which 97 is prolonged from daily collection to twice a week. 


$$
5 \text { of } 18
$$

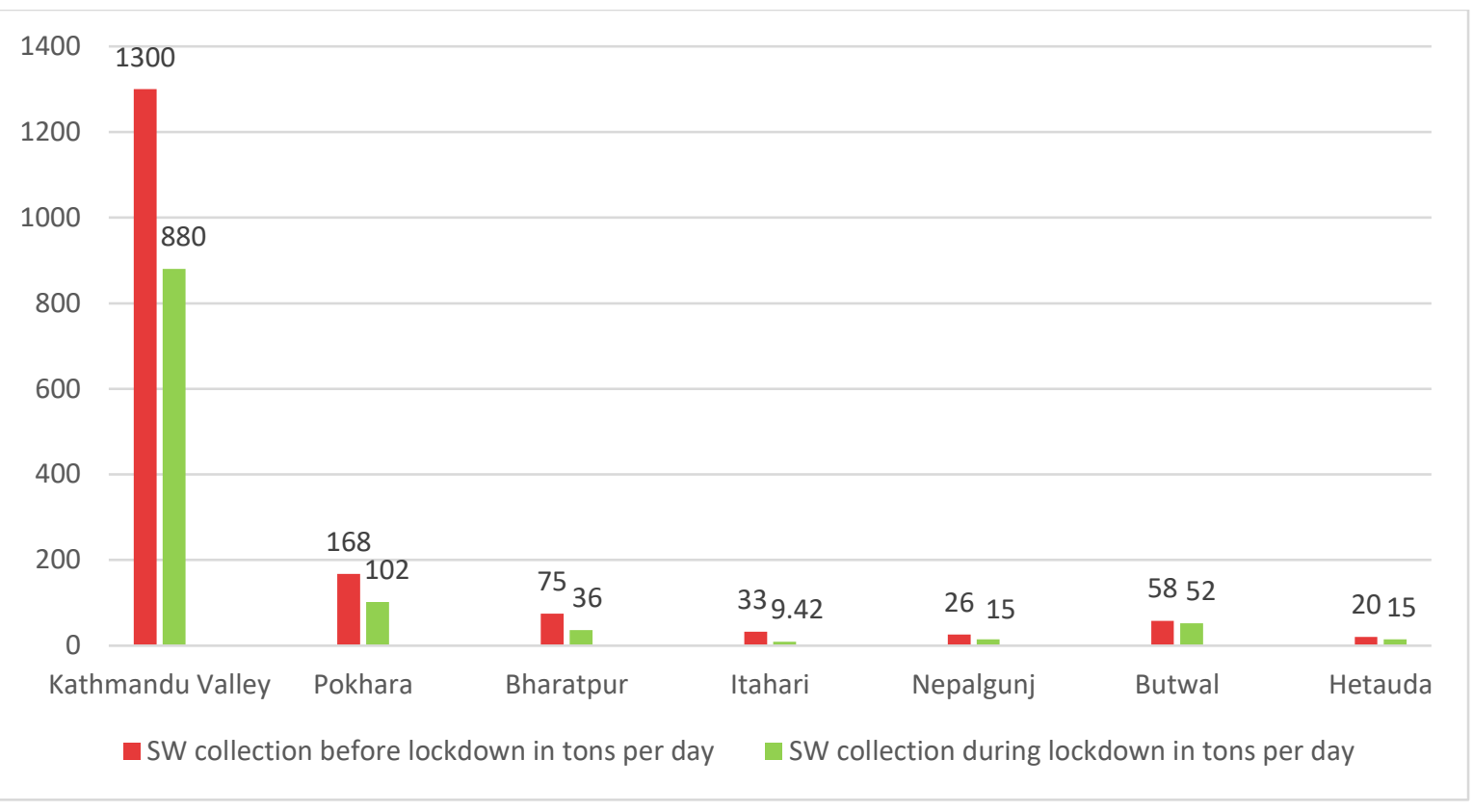

99 Figure 1(a). SW collection status in selected cities before and during lockdown

100

101

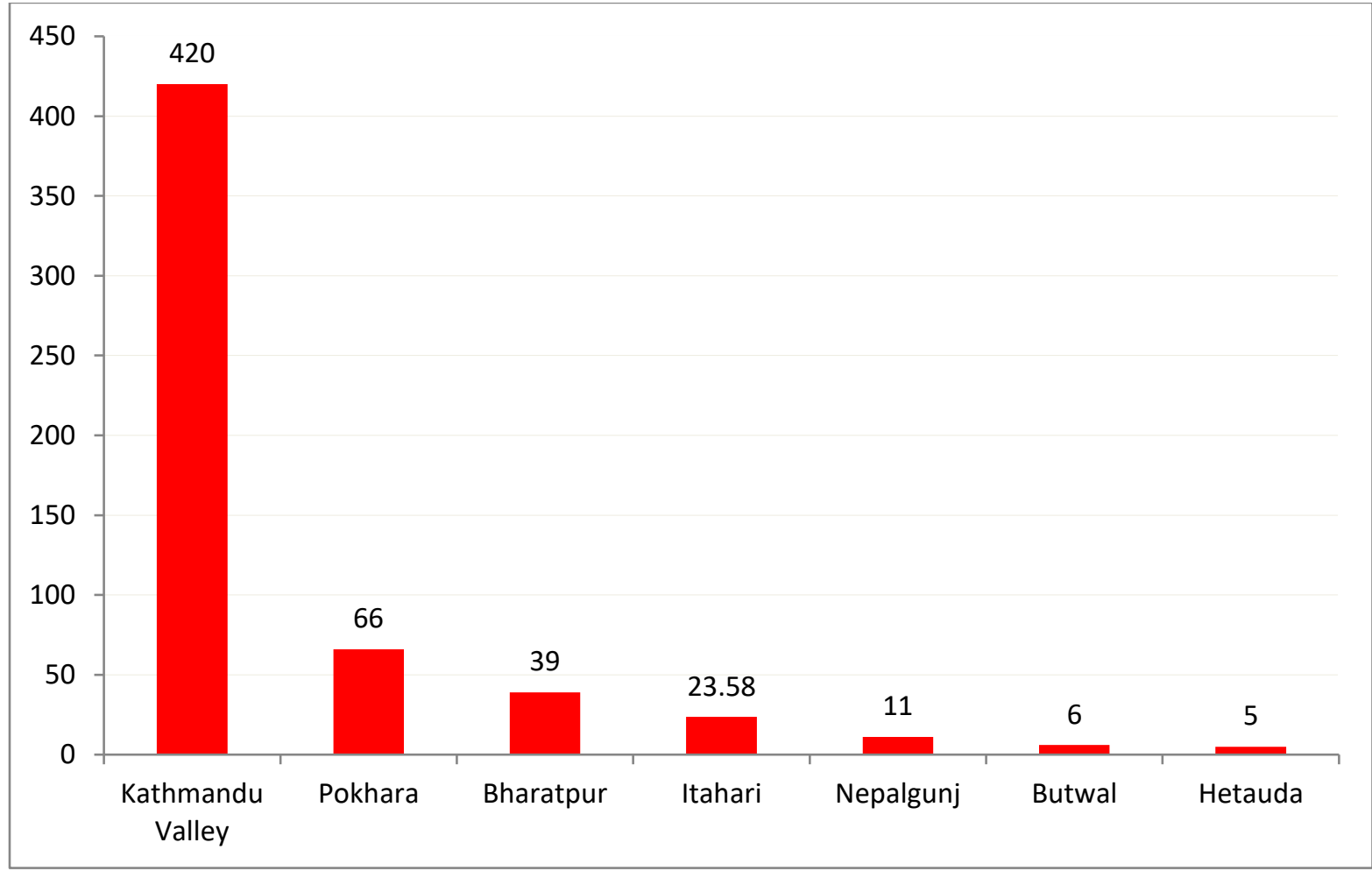

102 Figure 1(b). SW Collection Gap in tons per day

103 B. Respondent data before and during lockdown 


$$
6 \text { of } 18
$$

104 Table 2 shows number of respondents covered by each of the nine municipalities including all of its wards. The results

105

106

107

108

109

110

111

112

113

114

115

116

117

118

119

120

121

122

123

124

125

126

127

128

129

130

131

132

133

134

135

136

137

138 reveal that Pokhara metropolitan city covered highest percentage of respondents with 17.2\% followed by Kathmandu metropolitan city with coverage of $15.2 \%$. The figures were followed by Bharatpur Metropolitan, Butwal SubMetropolitan city, Lalitpur sub-metropolitan city, Nepalgunj Sub-Metropolitan city, Hetauda Sub-Metropolitan city, Itahari Sub-metropolitan city and Bhaktapur municipality with coverage of $12.9 \%, 11.2 \%, 11.0 \%, 9.3 \%, 8.7 \%, 8.1 \%$ and $6.6 \%$ respectively. The variations in the number of respondents of the individual places were observed based on survey form circulation rate and willingness of people to participate in the survey.

Table 3(a) and table 3(b) show the number of respondents reporting the frequency of solid waste collection in their households before and during the lockdown period. Figure 2(a) provides a brief overview of gap observed in the frequency of solid waste collection before and during lockdown. The results show that the respondents report a sharp decrease in the usual frequency of SW collection during lockdown. It is seen that $51.54 \%$ of the total respondents reported twice a week collection service before lockdown. Similarly, 32.36\% reported daily collection service, followed by $11.81 \%$ reporting once a week collection service and $1.13 \%$ reporting alternate day collection service in their household premises before lockdown. The results during lockdown reveal $54 \%$ of respondents reporting once a week collection service, $24.2 \%$ reporting twice a week collection service, $10.7 \%$ reporting twice a week collection service followed by $7.9 \%$ reporting daily collection service. In spite of municipal officials claiming similar waste collection coverage rates in all areas of their service operations, it can be seen that the average collection frequency of twice a week before lockdown has been dropped down to around once a week collection practices during lockdown. This leads to the accumulation of SW between the collection periods exacerbating the negative health and environmental impacts. Leachate dripping from the accumulated garbage also becomes common. The spread of unpleasant odour, insects and rodents around the accumulated wastes can be a major factor in the spread of insect borne gastro intestinal and parasitic diseases (such as gastroenteritis, dengue and malaria) in crowded communities. It has been found that accumulation of solid waste often in excess of seven days supports the breeding of Aedes aegypti and increases the transmission of dengue [13]. Thus, the gaps induced in SW collection practices due to the ongoing pandemic could induce other health pandemics in different cities of Nepal leading to worse situations of national health and economic indexes.

The survey reports $93.7 \%$ of respondents claiming protest by workers due to fear of virus as the reason behind the halt in collection services experienced during lockdown. While most of the people are forced indoors due to the lockdown, the sanitation workers continue to go from road-to-road-to-alley collecting garbage and sweeping the streets and they could come in contact with the objects that could host the coronavirus. Due to the unavailability of proper protective gears, the garbage collectors are at risk of exposure to Covid-19. Around 30\% of the 1800 formal and informal waste workers in Kathmandu had returned to their villages with the announcement of nation-wide lockdown. Even after the reopening of waste collection centers, there was strong hesitation among remaining workers to resume work. As a result, the capital city saw a sudden rise in solid waste mismanagement with piles of waste from households getting dumped on the sideways and the scenarios were similar at other cities as well. The World Health Organization (WHO)'s COVID-19 interim guidance report includes; “Best practices for protecting the health of workers at waste and 


$$
7 \text { of } 18
$$

139 sanitation treatment facilities should be followed. Workers should wear appropriate Personal Protective Equipment 140 (PPE), which includes protective outerwear, gloves, boots, goggles or a facial shield, and a mask and they should 141 perform hand hygiene frequently" [14]. Despite of this, the measures by the concerned authorities have not been 142 promising to help workers face the invisible enemy.

143

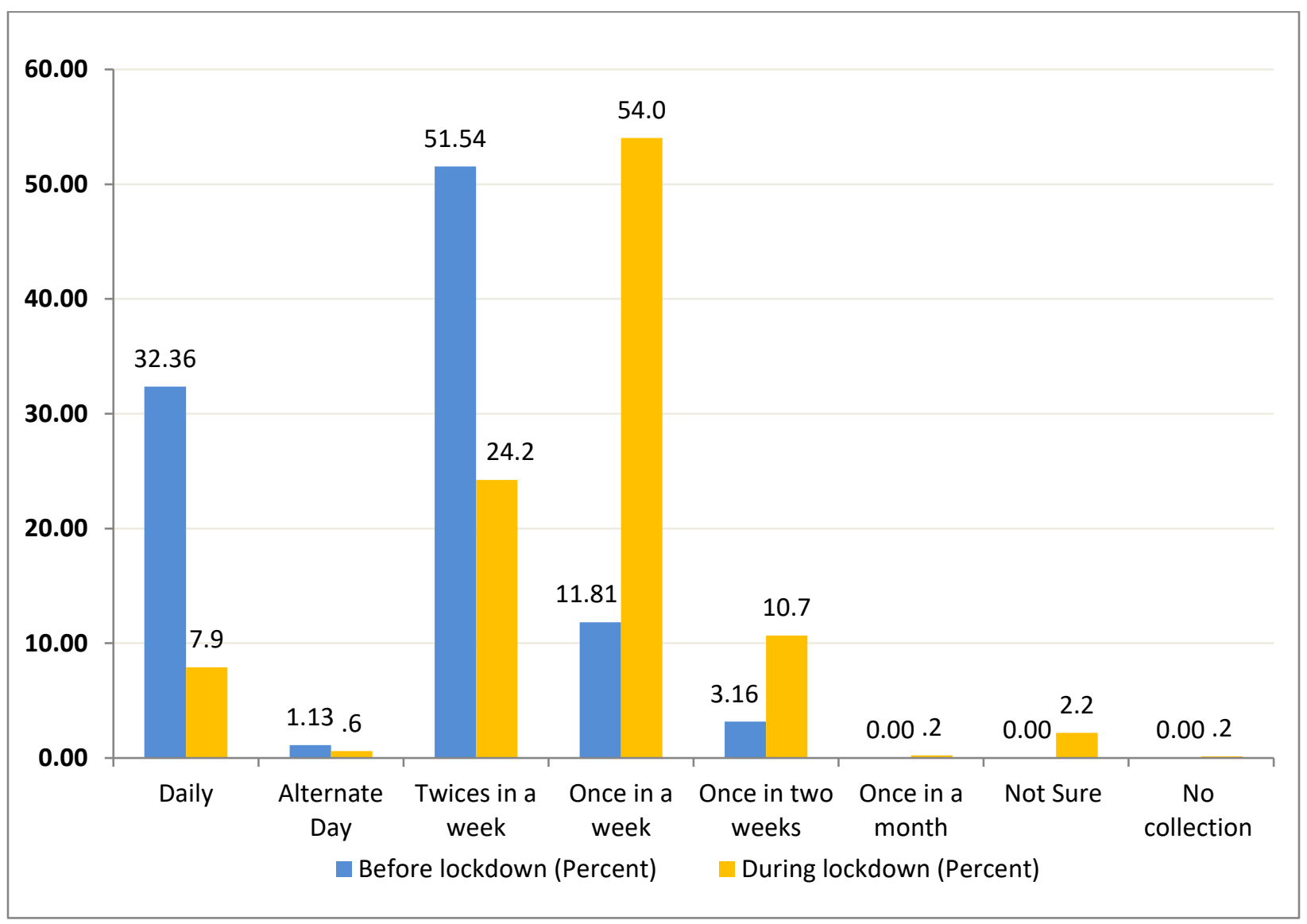

145 Figure 2(a). Frequency of SW collection before and during lockdown (in \%)

\subsection{Types of vehicles used for SW collection}

Table 4 gives the overview of the types of the vehicles operated for SW collection for the 9 cities studied.

150 Table 4: Types of vehicles used in SW Collection in 9 selected cities. Percentages and totals are based on responses.

\begin{tabular}{|c|c|c|c|c|c|c|c|c|}
\hline \multirow[b]{2}{*}{ Municipality } & & \multicolumn{6}{|c|}{ Type of vehicles used for the SW Collection } & \multirow[b]{2}{*}{ Total } \\
\hline & & $\begin{array}{l}\text { Dump } \\
\text { Trucks }\end{array}$ & $\begin{array}{r}\text { Mini } \\
\text { Trucks }\end{array}$ & Tractors & Tripper & $\begin{array}{r}\text { Rickshaws } \\
\text { and carts }\end{array}$ & $\begin{array}{r}\text { Van and } \\
\text { Others }\end{array}$ & \\
\hline \multirow{2}{*}{$\begin{array}{l}\text { Kathmandu } \\
\text { Metro. }\end{array}$} & Count & 133 & 10 & 39 & 14 & 24 & 1 & 221 \\
\hline & $\begin{array}{l}\text { \% within } \\
\text { MunicipalCode }\end{array}$ & $60.2 \%$ & $4.5 \%$ & $17.6 \%$ & $6.3 \%$ & $10.9 \%$ & $0.5 \%$ & \\
\hline
\end{tabular}




\section{8 of 18}

\begin{tabular}{|c|c|c|c|c|c|c|c|c|}
\hline I litnut & Count & 97 & 11 & 14 & 8 & 30 & 0 & 160 \\
\hline Sub-Metro. & $\begin{array}{l}\% \text { within } \\
\text { MunicipalCode }\end{array}$ & $60.6 \%$ & $6.9 \%$ & $8.8 \%$ & $5.0 \%$ & $18.8 \%$ & $0.0 \%$ & \\
\hline \multirow{2}{*}{$\begin{array}{l}\text { Bhaktapur } \\
\text { Mun. }\end{array}$} & Count & 36 & 0 & 34 & 20 & 1 & 0 & 91 \\
\hline & $\begin{array}{l}\% \text { within } \\
\text { MunicipalCode }\end{array}$ & $39.6 \%$ & $0.0 \%$ & $37.4 \%$ & $22.0 \%$ & $1.1 \%$ & $0.0 \%$ & \\
\hline \multirow[b]{2}{*}{$\begin{array}{l}\text { Bharatpur } \\
\text { Metro }\end{array}$} & Count & 23 & 0 & 96 & 53 & 0 & 0 & 172 \\
\hline & $\begin{array}{l}\% \text { within } \\
\text { MunicipalCode }\end{array}$ & $13.4 \%$ & $0.0 \%$ & $55.8 \%$ & $30.8 \%$ & $0.0 \%$ & $0.0 \%$ & \\
\hline \multirow{2}{*}{$\begin{array}{l}\text { Hetauda } \\
\text { Sub-Metro. }\end{array}$} & Count & 25 & 4 & 73 & 11 & 12 & 0 & 125 \\
\hline & $\begin{array}{l}\text { \% within } \\
\text { MunicipalCode }\end{array}$ & $20.0 \%$ & $3.2 \%$ & $58.4 \%$ & $8.8 \%$ & $9.6 \%$ & $0.0 \%$ & \\
\hline \multirow{2}{*}{$\begin{array}{l}\text { Itahari Sub- } \\
\text { Metro. }\end{array}$} & Count & 3 & 0 & 104 & 0 & 1 & 0 & 108 \\
\hline & $\begin{array}{l}\% \text { within } \\
\text { MunicipalCode }\end{array}$ & $2.8 \%$ & $0.0 \%$ & $96.3 \%$ & $0.0 \%$ & $.9 \%$ & $0.0 \%$ & \\
\hline \multirow{2}{*}{$\begin{array}{l}\text { Pokhara } \\
\text { Metro. }\end{array}$} & Count & 142 & 0 & 4 & 82 & 0 & 0 & 228 \\
\hline & $\begin{array}{l}\% \text { within } \\
\text { MunicipalCode }\end{array}$ & $62.3 \%$ & $0.0 \%$ & $1.8 \%$ & $36.0 \%$ & $0.0 \%$ & $0.0 \%$ & \\
\hline \multirow{2}{*}{$\begin{array}{l}\text { Butwal Sub- } \\
\text { Metro. }\end{array}$} & Count & 5 & 0 & 127 & 12 & 7 & 0 & 151 \\
\hline & $\begin{array}{l}\% \text { within } \\
\text { MunicipalCode }\end{array}$ & $3.3 \%$ & $0.0 \%$ & $84.1 \%$ & $7.9 \%$ & $4.6 \%$ & $0.0 \%$ & \\
\hline \multirow[b]{2}{*}{$\begin{array}{l}\text { Nepalgunj } \\
\text { Sub-Metro. }\end{array}$} & Count & 22 & 0 & 81 & 1 & 24 & 1 & 129 \\
\hline & $\begin{array}{l}\text { \% within } \\
\text { MunicipalCode }\end{array}$ & $17.1 \%$ & $0.0 \%$ & $62.8 \%$ & $.8 \%$ & $18.6 \%$ & $.8 \%$ & \\
\hline \multirow{2}{*}{ Total } & Count & 486 & 25 & 572 & 201 & 99 & 2 & 1385 \\
\hline & $\%$ of Total & $35.1 \%$ & $1.8 \%$ & $41.3 \%$ & $14.5 \%$ & $7.1 \%$ & $.1 \%$ & $100.0 \%$ \\
\hline
\end{tabular}

152 Figures 3(a) to 3(i) portray the survey results on types of vehicles operated at household level in each of the nine

153 selected cities. The wastes collected by these vehicles are disposed at respective transfer stations before the final

154 disposal at the landfill sites. Out of the nine cities chosen for study, it was found that Butwal and Hetauda had

155 composting plants at the final waste disposal sites. However, Butwal Sub-Metro reports experiencing halts in the

156 operation of composting plant due to technical issues. From the figures it could be seen that Kathmandu Metropolitan

157 City, Lalitpur Sub-Metropolitan City and Pokhara Metropolitan City show highest use of dump trucks for SW

158 collection whereas the remaining six cities namely Bhaktapur Municipality, Bharatpur Metropolitan city, Hetauda Sub-

159 Metropolitan city, Butwal Sub-Metropolitan City and Nepalgunj Sub-Metropolitan city show maximum usage of

160 tractors for SW collection. The circulated usage of dump trucks and trippers could be seen more in metropolitan and

161 sub-metropolitan cities with higher population density and improved road facilities followed by the cluster of tractors,

162 mini-trucks, rickshaws and carts usage in semi-urban areas comprising of relatively smaller road networks and lower

163 population density. The variation of figures could be noticed in Bhaktapur municipality reporting similar ratios of

164 dump trucks (39.6\%) and tractors (37.4\%) usage followed by trippers $(22 \%)$ for SW collection. This is because along

165 with urban areas, the municipality also consists of some semi-urban and rural area networks with limited road access;

166 which fosters the use of tractors. 


\section{9 of 18}

167

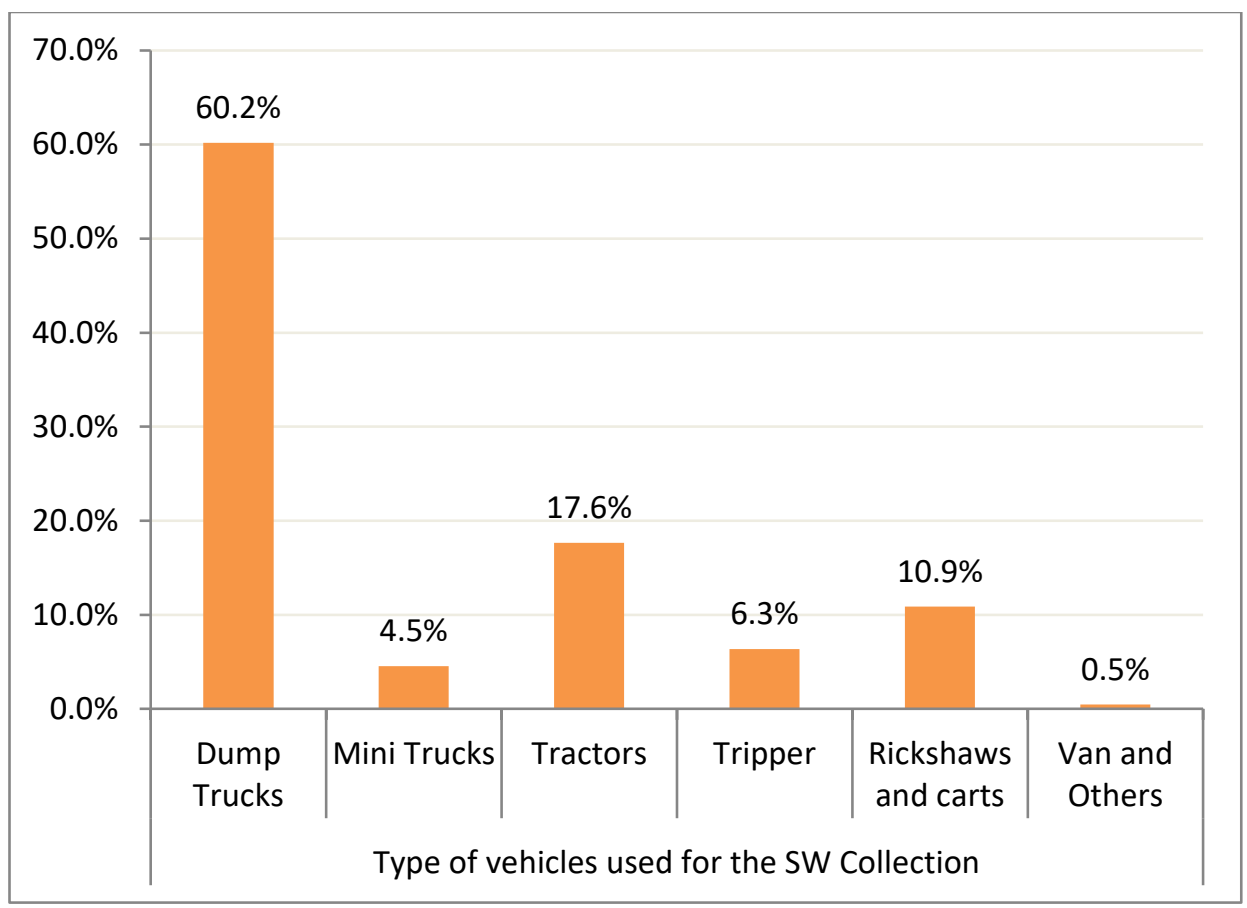

169 Figure 3(a). Types of vehicle used for SW collection in Kathmandu Metropolitan city

170

171

172

173

174

175 
10 of 18

176

177

178

179

180

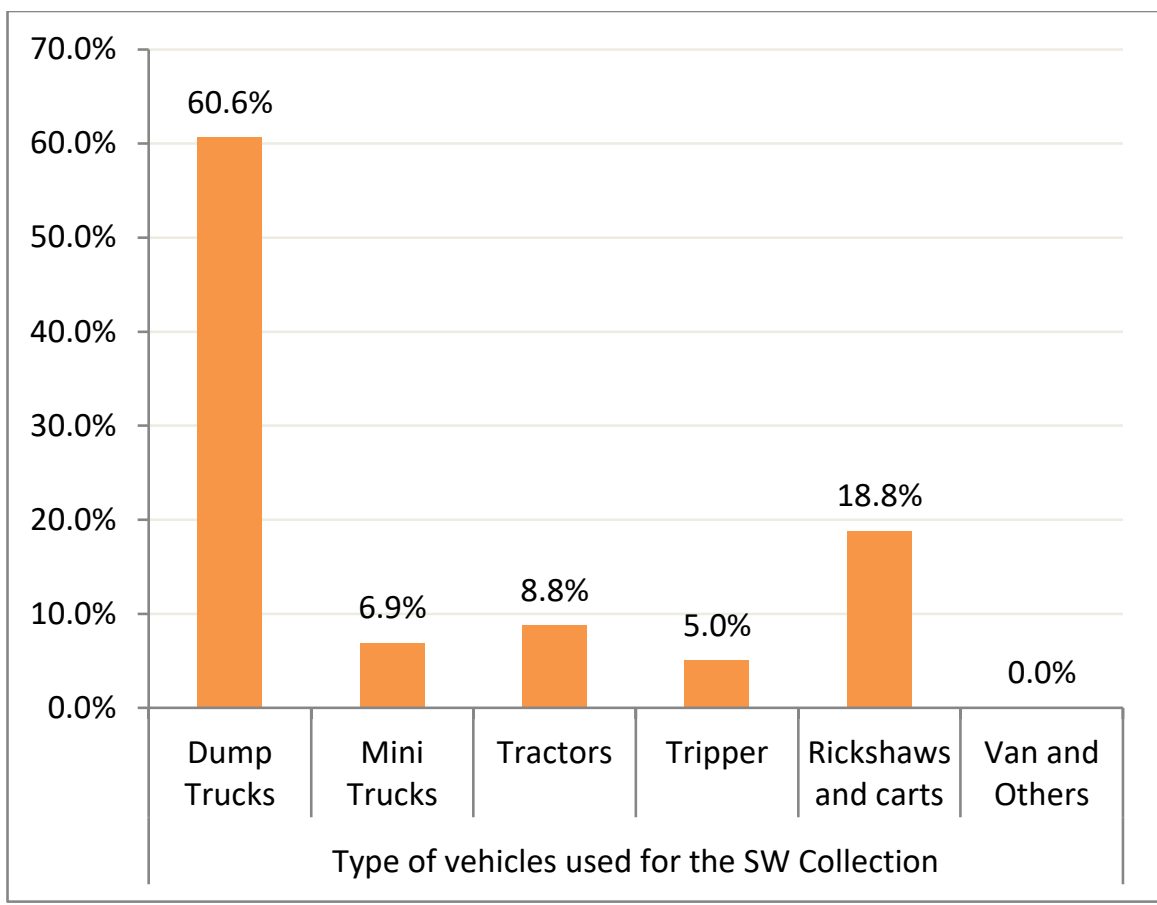

Figure 3(b). Types of vehicle used for SW collection in Lalitpur Sub- Metropolitan

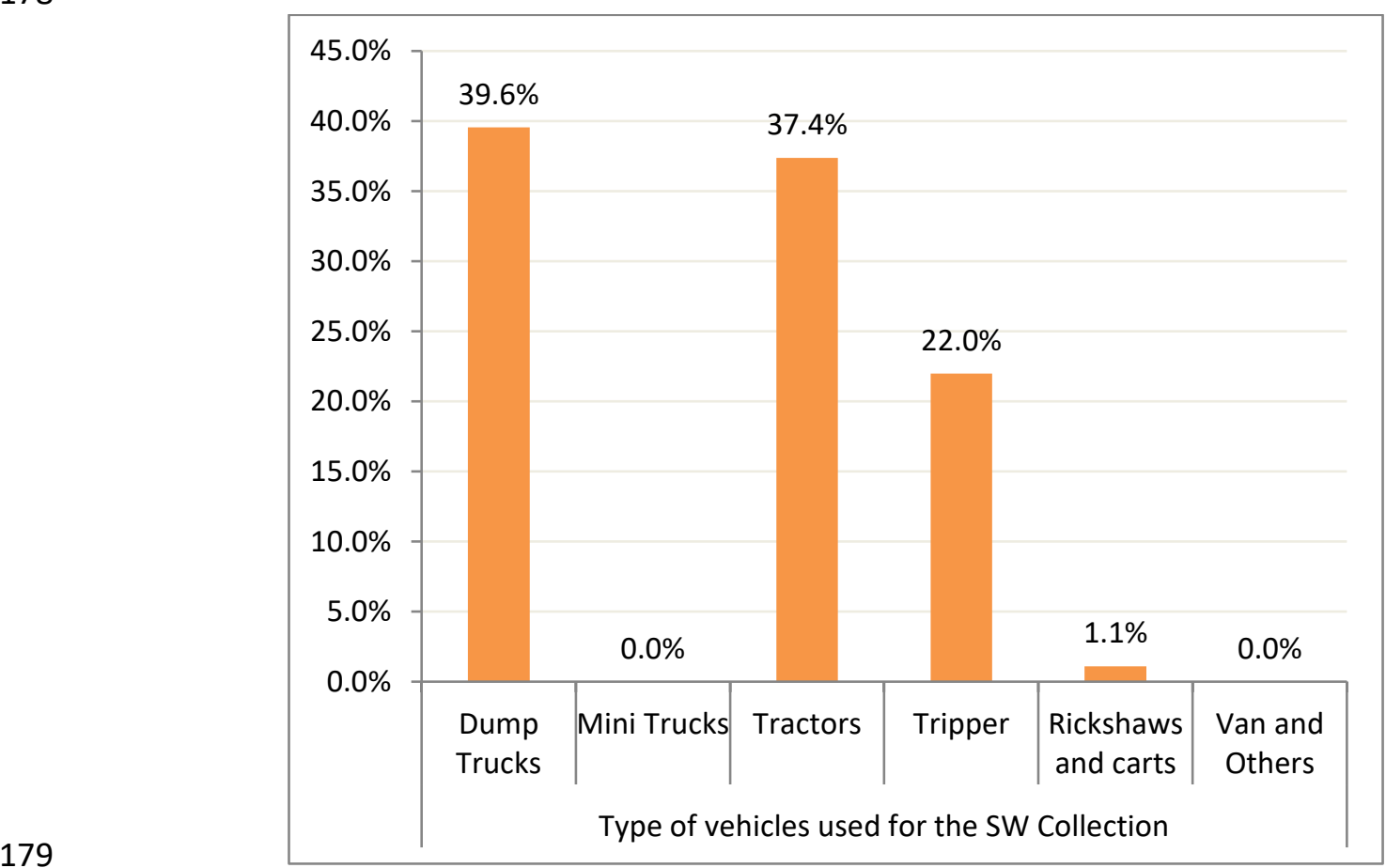

Figure 3(c). Types of vehicle used for SW collection in Bhaktapur Municipality 
11 of 18

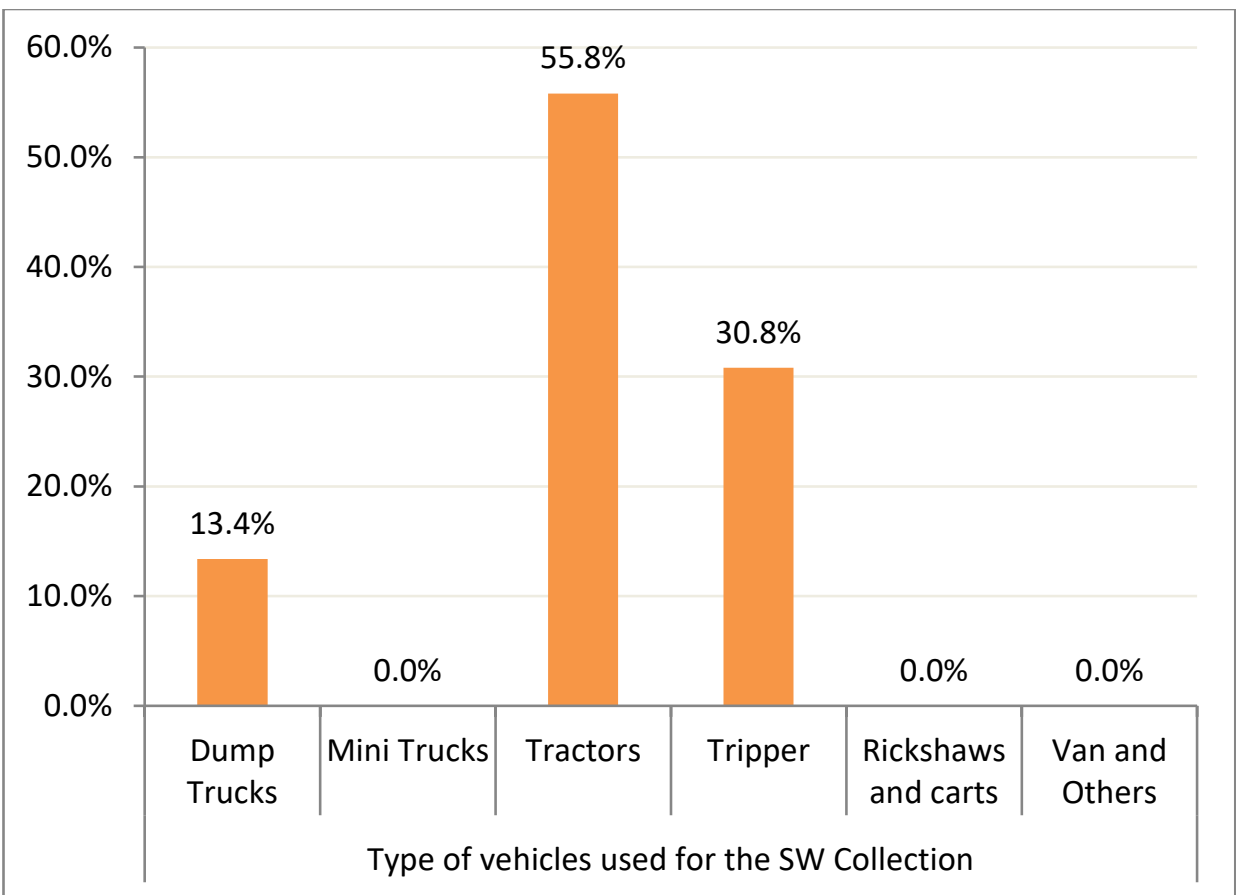

Figure 3(d). Types of vehicle used for SW collection in Bharatpur Metropolitan 
12 of 18

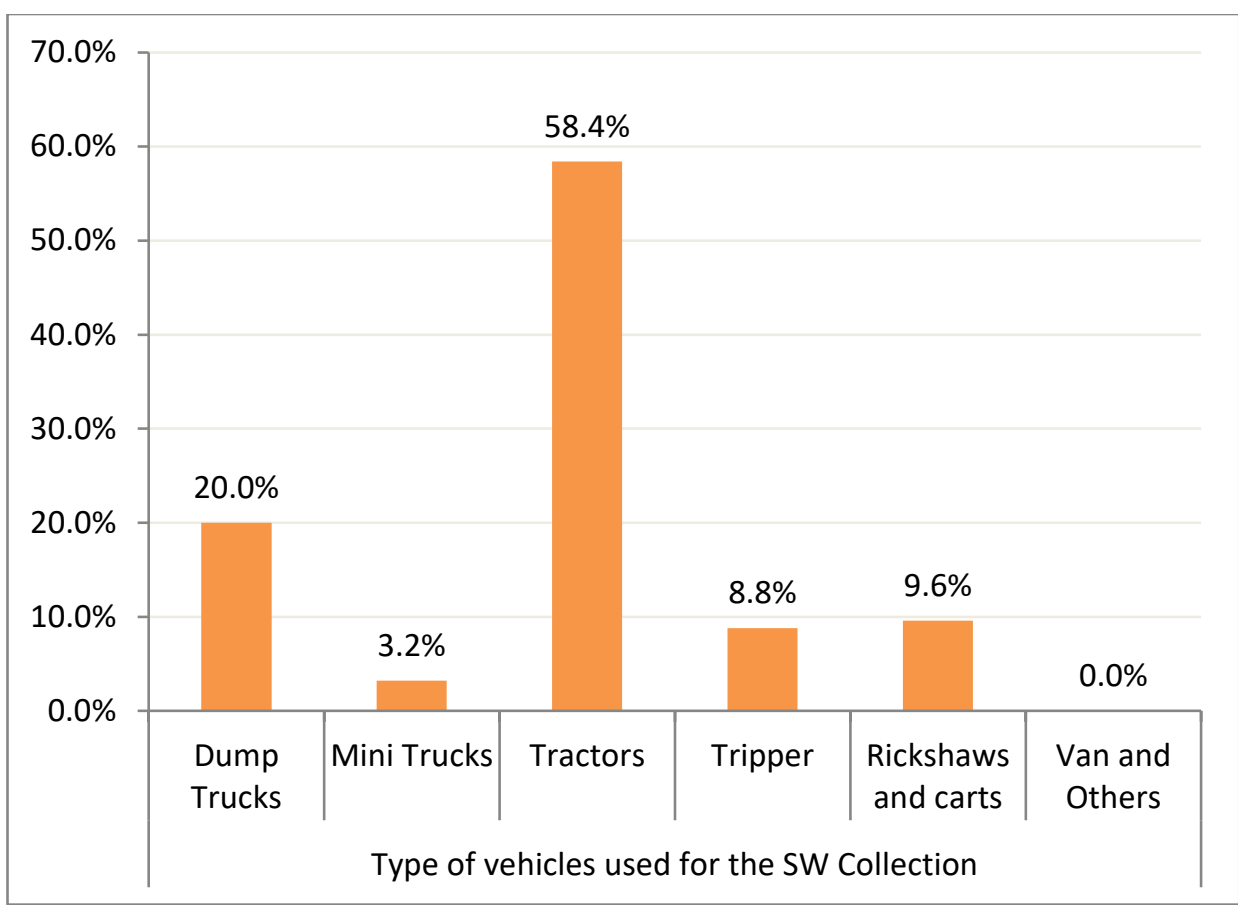

Figure 3(e). Types of vehicle used for SW collection in Hetauda Sub-Metropolitan

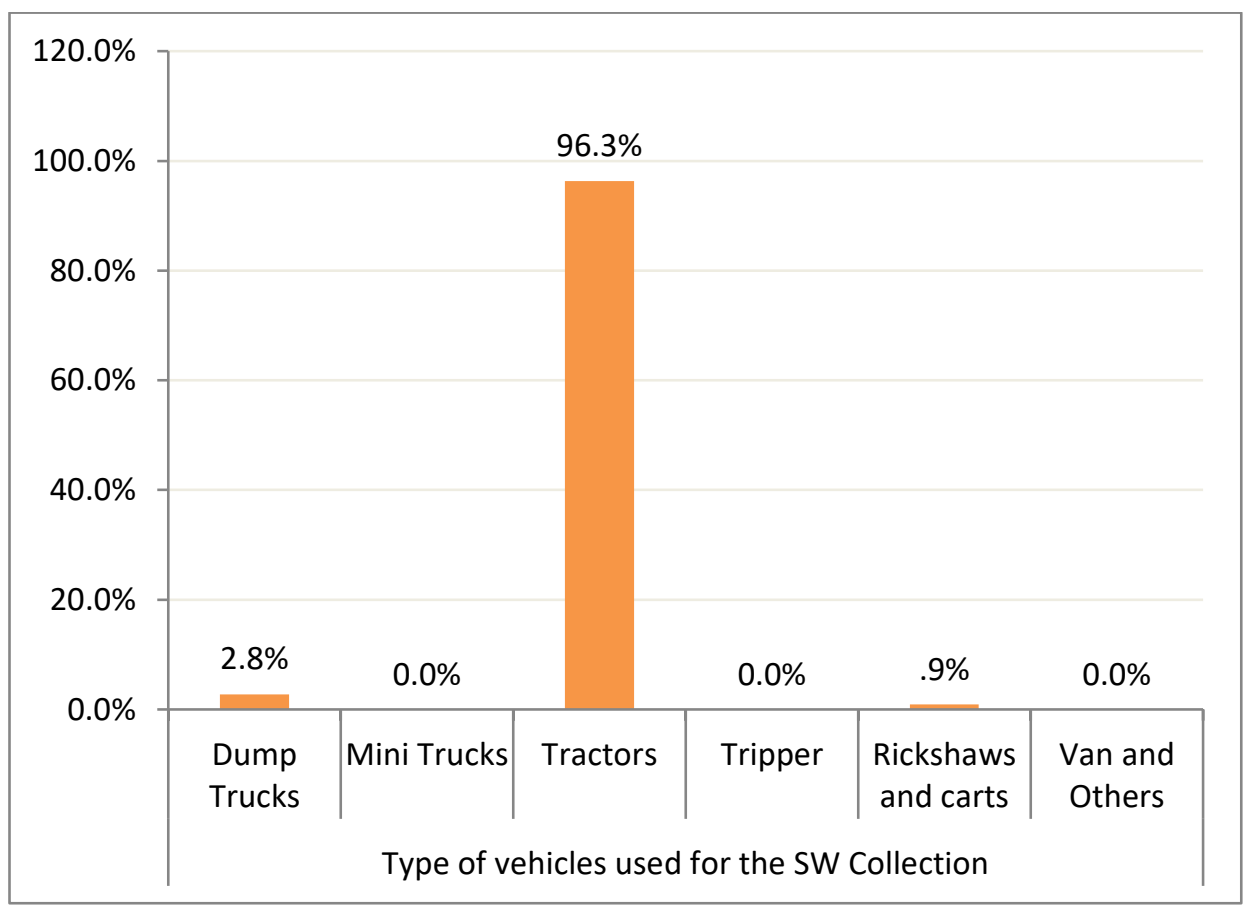

Figure 3(f). Types of vehicle used for SW collection in Itahari Sub-Metropolitan 
13 of 18

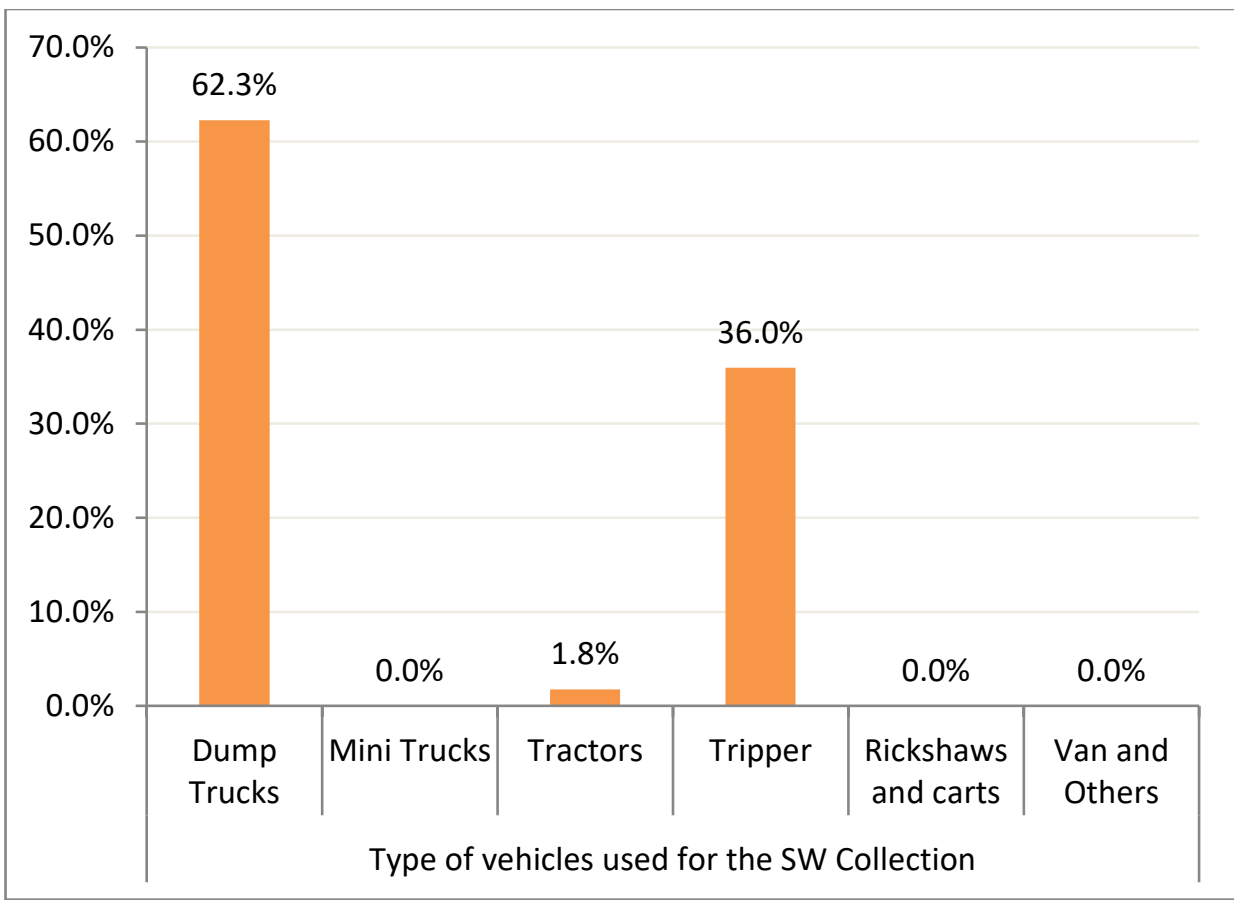

Figure 3(g). Types of vehicle used for SW collection in Pokhara Metropolitan

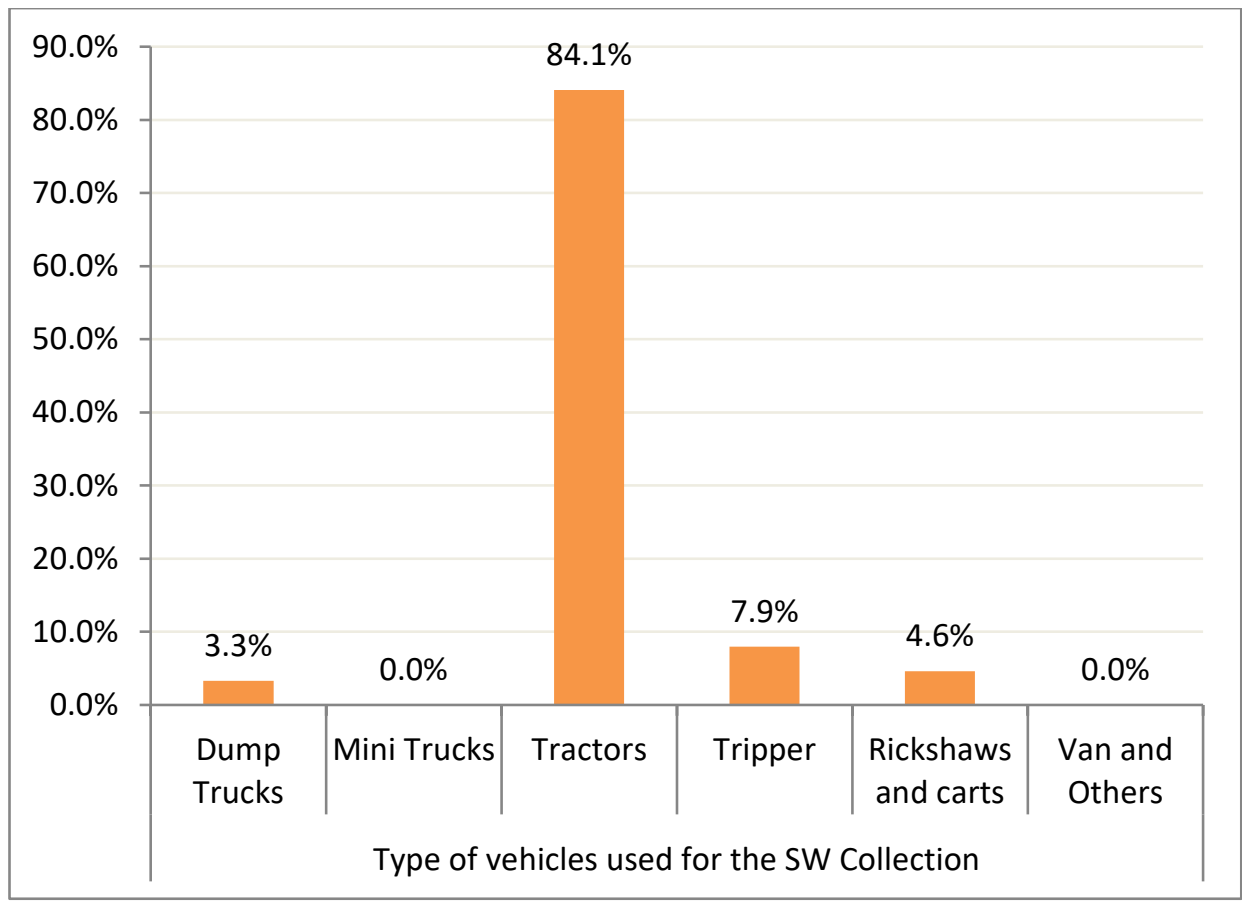

Figure 3(h). Types of vehicle used for SW collection in Butwal Sub-Metropolitan 
14 of 18

\subsection{SW management methods adopted by households}

Figure 4(a) portrays the overall picture of the alternative solid waste management methods adopted by households during the municipal solid waste collection gap.The results from figure $4(\mathrm{a})$ reveal $52.4 \%$ of the respondents storing waste with proper management, $18.9 \%$ practicing burning of wastes, $25.7 \%$ practicing land composting and $1.2 \%$ throwing wastes in streets. With half of the respondents claiming storing waste with proper management, the practice somehow has positive side as it indirectly induces the reduction of wastes at household level. However, the accumulated wastes can be hazardous and can contaminate the surrounding if not handled properly. Organic domestic waste poses a serious threat, since they ferment and create conditions favorable to the survival and growth of microbial pathogens like Enterobacteriaceae, Shigella, Chlamydia trachomatis etc. The odor and leachate generation from accumulated wastes make favorable conditions for insects, flies and rodents to breed around them inducing a number of bacterial diseases like salmonellosis, shigellosis, staphylococcal food poisoning along with viral diseases like trachoma, gastroenteritis etc. As a result, the prolonged storage of SW at household level doesn't seem to be an effective method. It is worrisome to see from the results in Figure 4(a) that 18.9\% practice burning of wastes lacking proper health and safety requirements. The main justification for why many areas practice waste burning as one of the SW management methods is volume reduction. However, studies reveal that open burning release toxic like nitrogen oxides, sulfur dioxide, volatile organic chemicals (VOCs) and carcinogenic gases like polycyclic organic matter (POMs), benzo(a)pyrene (BAP) and polyaromatic hydrocarbons (PAHs); specially if the waste contains plastic materials. People practicing open burning are found to be at greater risks of chronic respiratory diseases, including cancers resulting 
15 of 18

218 from exposures of dust and hazardous compounds. The released gases also impose long term effects on the

219 environment and groundwater. It is seen that $25.7 \%$ of the respondents reported land composting as their alternatives

220 to SW management at household level during the induced collection gap which is as one of the best methods of

221 maintaining and enhancing the fertility of the soil. The transformation of organic waste products into humus rich soil

222 teeming with beneficial microbes certainly carries a great value but the alternative doesn't seem feasible to majority of

223 housings in the chosen cities of Nepal where ample land is being changed into private and commercialized living

224 quarters in the verge of rapid urbanization. The households are confined in clusters with one other holding

225 concentrated population and thus the amount required for land composting isn't available in most of the cases. It was

226 noticed $1.2 \%$ of the respondents reported throwing wastes in streets which induces outbreaks of other diseases.

227 Moreover, leachate from such random dumps contaminates groundwater in the long run 


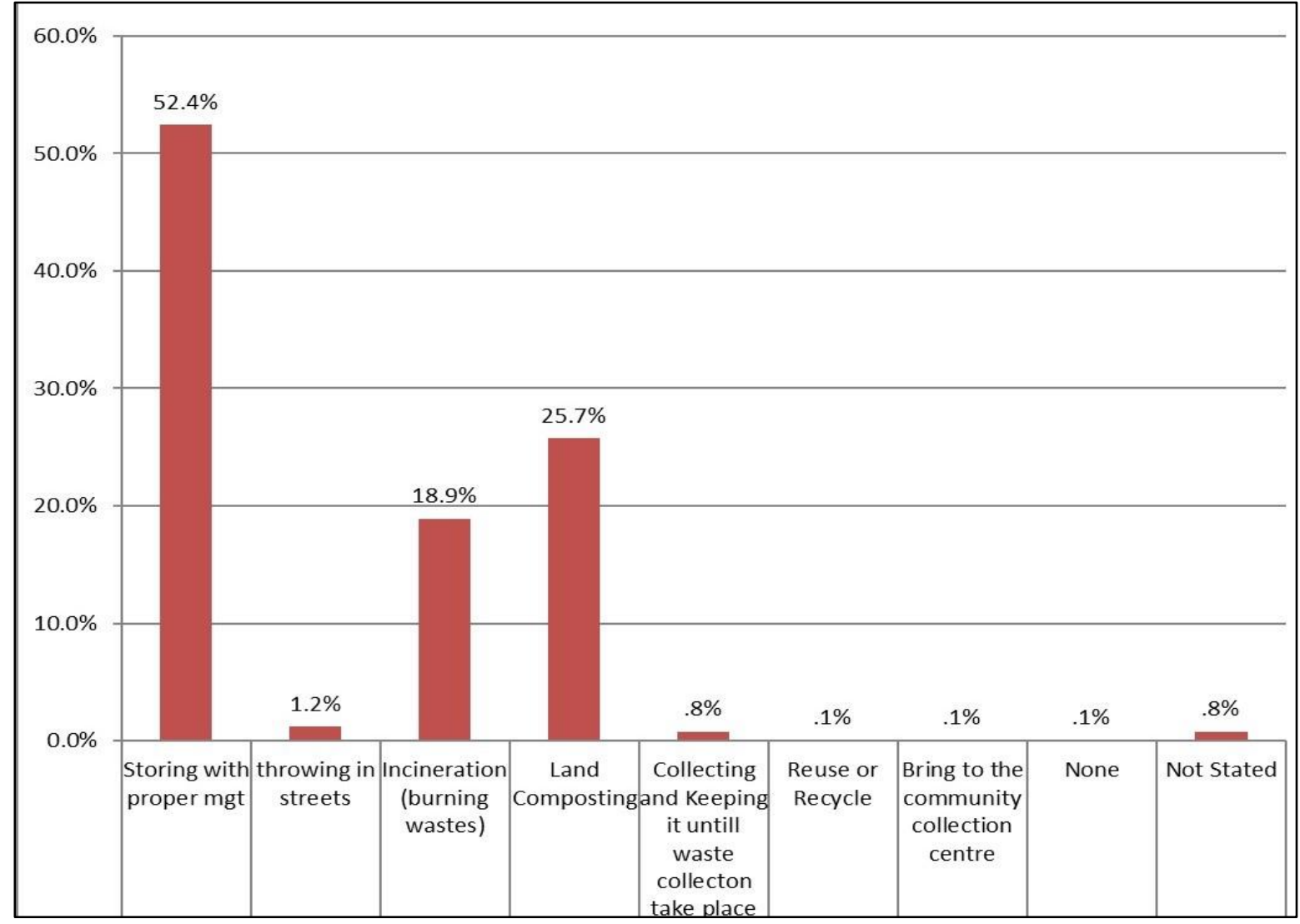

Figure 4. SW management methods adopted by households in selected cities during lockdown

\section{CONCLUSION}

231 The study shows the nation-wide lockdown due to COVID-19 led to SW collection gap of 560.58 tons/day in 9

232 major cities of Nepal and the scenario is likely to get worse inducing other health risks if the service remains

233 unattended by concerned authorities. It has been found that in spite of being aware of modes of transmission

234 and safety measures, the solid waste workers are at high risk of exposure towards the virus due to inadequate

235 and non-uniform distribution of safety gears. This could further lead to worse contexts with solid waste workers

236 being the modes for retransmission of virus to the community. Along with other essential sectors, the

237 government should prioritize safety and insurance of solid waste workers as well since the continual priority to

238 health sector alone cannot reduce the COVID-19 vulnerability.

239 The study reports waste workers in some places not being supported by their localities which adds to the 240 primary cause of strong hesitation by workers to resume their work. It is necessary for the public to understand

241 the gist of the service and develop an attitude of respect towards the solid waste workers as they have been 242 continuing their works in spite of occupational health risk exposures. 
Based on findings of study it could be seen that the practice of municipal vehicles collecting wastes from door to door, roads, alleys has made public less concerned towards managing the organic wastes at household level.

Even at the scenarios of decreased SW collection frequency during lockdown, the survey shows public attitude towards household waste management to be relatively similar with the preceding contexts. Solid Waste Management being an invaluable public health service holds additional value during the pandemic. The ones getting continual services from formal and informal waste management organizations are privileged enough to have been benefited tremendously from avoiding the health risks of stockpiling of solid wastes. The study shows the urgency of an effective emergency response plan to be developed by the government for the preparedness during such crisis in order to supplement the waste sector with uninterrupted services. A general interim guidance for workers on the sector holds critical importance to decrease the risk of occupational exposure to SARS-CoV-2. The study concludes that the uninterrupted SW collection service during the pandemic is utmost and requires sound understanding, participation and co-ordination of activities between waste management authorities, solid waste workers and public.

Author Contributions: B.A. conceived and designed the research. B.A. gathered, processed and analyzed the data. S.K. and B.A. contributed to discussing the results and writing the paper.

Conflicts of Interest: The authors declare no conflict of interest.

\section{REFERENCES}

1. De Feo, G., Ferrara, C., Iannone, V., \& Parente, P. (2019). Improving the efficacy of municipal solid waste collection with a communicative approach based on easily understandable indicators. Science of the Total Environment, 651, 2380-2390. https://doi.org/10.1016/j.scitotenv.2018.10.161

2. Minelgaitè, A., \& Liobikienè, G. (2019). Waste problem in European Union and its influence on waste management behaviours. Science of the Total Environment, 667, 86-93. https://doi.org/10.1016/j.scitotenv.2019.02.313

3. Stoeva, K., \& Alriksson, S. (2017). Influence of recycling programmes on waste separation behaviour. Waste Management, 68, 732-741. https://doi.org/10.1016/j.wasman.2017.06.005

4. D'Amato, A., Mancinelli, S., \& Zoli, M. (2016). Complementarity vs substitutability in waste management behaviors. Ecological Economics, 123, 84-94. https://doi.org/10.1016/j.ecolecon.2015.12.005

5. Saxena, S., Srivastava, R. K., \& Samaddar, a B. (2010). Sustainable Waste Management Issues in India. The IUP Journal of Soil and Water Sciences, III(1), 72-90.

6. Zhu, D., Asnani, P. U., Zurbrügg, C., Anapolsky, S., \& Mani, S. (2008). Improving Municipal Solid Waste Management in India : A Sourcebook for Policy Makers. https://doi.org/10.1596 978- 
0-8213-7361-3

7. Gupta, N., Yadav, K. K., \& Kumar, V. (2015). A review on current status of municipal solid waste management in India. Journal of Environmental Sciences (China), 37, 206-217. https://doi.org/10.1016/j.jes.2015.01.034

8. World Bank. (2012). A Global Review of Solid Waste Management - Review, Global Management, Solid Waste. World Bank Urban Development Series Knowledge Papers, January 2012, 1-116.

9. Guerrero, L. A., Maas, G., \& Hogland, W. (2013). Solid waste management challenges for cities in developing countries. Waste Management, 33(1), 220-232. https://doi.org/10.1016/j.wasman.2012.09.008

10. Minghua, Z., Xiumin, F., Rovetta, A., Qichang, H., Vicentini, F., Bingkai, L., Giusti, A., \& Yi, L. (2009). Municipal solid waste management in Pudong New Area, China. Waste Management, 29(3), 1227-1233. https://doi.org/10.1016/j.wasman.2008.07.016

11. Mol, M. P. G., \& Caldas, S. (2020). Can the human coronavirus epidemic also spread through solid waste? Waste Management and Research, 38(5), 485-486. https://doi.org/10.1177/0734242X20918312

12. Laurent, A., Bakas, I., Clavreul, J., Bernstad, A., Niero, M., Gentil, E., Hauschild, M. Z., \& Christensen, T. H. (2014). Review of LCA studies of solid waste management systems - Part I: Lessons learned and perspectives. Waste Management, 34(3), 573-588. https://doi.org/10.1016/j.wasman.2013.10.045

13. Abeyewickreme, W., Wickremasinghe, A. R., Karunatilake, K., Sommerfeld, J., \& Axel, K. (2012). Community mobilization and household level waste management for dengue vector control in Gampaha district of Sri Lanka; an intervention study. Pathogens and Global Health, 106(8), 479-487. https://doi.org/10.1179/2047773212Y.0000000060

14. World Health Organization (WHO), \& (UNICEF), U. N. C. F. (2020). Water, sanitation, hygiene and waste management for the COVID-19 virus. World Health Organization, 1(March), 1-9. 